\title{
Studi Komunikasi Politik Legislator Perempuan Di DPRD Provinsi NTB
}

\author{
Oleh: Hartin Nur Khusnia ${ }^{1}$, Muhlis² ${ }^{2}$ Tenri Waru ${ }^{3}$
}

1. Program Studi Ilmu Komunikasi, Universitas Mataram

2. Program Studi Ilmu Komunikasi Universitas Mataram

3. Program Studi Ilmu Komunikasi Universitas 45 Mataram

\begin{abstract}
Equality of rights and obligations between men and women has been textually stated and guaranteed by various regulations, both at international, national and local levels. However, this guarantee does not necessarily guarantee equality between men and women to actively participate in practical politics. The fact that the representation of women in legislator of the West Nusa Tenggara Province is still low, which a total of 65 members of the Regional House of West Nusa Tenggara Province Representatives for the 2014-2016 periode 6 female legislators and 59 male legislators. The object of this research study is the political communication of women's legislators in the Regional House of Representatives of West Nusa Tenggara Province. The results of interviews with research informants can be concluded that the political communication of female legislators in the Regional House of Representatives of West Nusa Tenggara Province runs effectively because it is influenced by internal and external factors. Internal factors are the personal abilities of female politicians in building positive self-concepts. While external factors are participatory political culture in both the legislative and political parties where politicians take shelter. Political communication activities carried out by women's legislators aim to influence political policy, especially policies related to women's empowerment in West Nusa Tenggara. And aims to establish the self-image of politicians and institutions, both political parties or legislative bodies.
\end{abstract}

Keywords: Political Communication, Women's Legislators, the Regional House of Representatives of West Nusa Tenggara Province

\begin{abstract}
ABSTRAK
Kesetaraan hak dan kewajiban antara laki-laki dan perempuan secara tekstual telah dinyatakan dan dijamin oleh berbagai peraturan, baik di tingkat internasional, nasional, maupun lokal. Namun, jaminan ini tidak serta merta menjamin kesetaraan antara laki-laki dan perempuan untuk berpartisipasi aktif dalam politik praktis. Faktanya keterwakilan perempuan di lembaga legislatif provinsi NTB masih rendah, dimana dari total 65 anggota DPRD Provinsi NTB periode 2014-2016 jumlah legislator perempuan sebanyak 6 orang dan 59 lainnya adalah legislator laki-laki. Objek kajian penelitian ini adalah komunikasi politik legislator perempuan di DPRD Provinsi NTB. Hasil wawancara dengan informan penelitian dapat disimpulkan bahwa komunikasi politik legislator perempuan di DPRD Provinsi NTB berjalan secara efektif karena dipengaruhi oleh faktor internal dan eksternal. Faktor internal adalah kemampuan personal politisi perempuan dalam membangun konsep diri yang positif. Sementara faktor eksternal adalah budaya politik partisipatif baik di lembaga legislatif maupun partai politik tempat politisi bernaung. Kegiatan komunikasi politik yang dilakukan oleh legislator perempuan bertujuan untuk mempengaruhi kebijakan politik, terutama kebijakan yang
\end{abstract}


terkait dengan pemberdayaan perempuan di NTB. Serta bertujuan untuk pembentukan citra diri politisi dan lembaga, baik partai politik ataupun badan legislatif.

Kata Kunci: Komunikasi Politik, Legislator Perempuan, DPRD Provinsi NTB

\section{PENDAHULUAN}

Undang-Undang Dasar Negara Republik Indonesia Tahun 1945 Pasal 27 ayat (1), menyatakan secara tegas bahwa segala warga negara bersamaan kedudukannya di dalam hukum dan pemerintahan. Ini berarti bahwa setiap warga negara baik laki-laki dan perempuan sama-sama memiliki hak yang setara dalam segala bentuk kehidupan di masyarakat, termasuk dalam politik. Selain dalam UUD 1945, hak-hak warga negara untuk berpartisipasi dalam politik sebagai bentuk implementasi demokrasi juga diatur dalam Undang-Undang Politik, Undang-Undang Pemilihan Umum, dan Pemilihan Presiden dan Wakil Presiden, Undang-Undang Pemerintah Daerah dan peraturan-peraturan lainnya.

Jaminan secara hukum terhadap peran perempuan dalam politik ini tidak diiringi oleh jaminan dalam sistem sosial masyarakat. Fakta di lapangan peran perempuan dalam politik di Indonesia masih minim, baik di tingkat nasional maupun daerah. Salah satu faktanya adalah jumlah keterwakilan perempuan di legislatif tahun 2014-2019 adalah 17.32\%, sementara keterwakilan perempuan di DPRD Provinsi NTB tahun 2014-2019 adalah 9.23\% dengan jumlah 6 anggota legislatif perempuan dan 59 laki-laki. Keterlibatan perempuan dalam politik yang minim ini dikarenakan sistem sosial masyarakat yang tidak pro terhadap peran aktif perempuan di ruang publik. Stigma negatif terhadap perempuan yang direproduksi secara terus menerus mengakibatkan kaum perempuan menjadi kelompok yang marginal di ruang publik, khususnya politik. Secara praktis kehadiran perempuan dalam politik masih dipandang sebelah mata, stigma tentang perempuan sebagai kaum yang lemah, tidak rasional, hanya menjadi konco wingking saja, membuat perempuan tidak leluasa berkiprah dalam politik, terlebih dunia politik ini oleh masyarakat seringkali diidentikkan sebagai dunianya lakilaki.

Budaya yang berkembang dalam sistem sosial masyarakat ini tentunya akan berpengaruh terhadap budaya politik itu sendiri. Sementara, budaya politik masyarakat dimana sebuah sistem politik berlangsung akan mempengaruhi pelaksanaan fungsi sistem politik termasuk didalamnya komunikasi politik. Oleh karenanya penelitian ini akan mengkaji bagaimana komunikasi politik yang dilakukan oleh para legislator perempuan di DPRD Provinsi NTB, mengingat para legislator perempuan ini berkiprah aktif dalam politik dalam kondisi sistem sosial masyarakat yang kurang mendukung terhadap partisipasi perempuan dalam politik. Sementara, keterwakilan perempuan di parlemen mempunyai fungsi tertentu, salah satunya adalah bagaimana legislator perempuan ini mampu mempengaruhi dan menghasilkan kebijakan-kebijakan pemerintah yang pro terhadap kaum perempuan, seperti masalah kesehatan, pendidikan, ekonomi, dan sebagainya. Oleh karenanya, dibutuhkan kemampuan komunikasi politik agar keberadaan legislator perempuan di parlemen ini benar-benar mampu menjadi perwakilan kepentingan kaum perempuan.

\section{TINJAUAN PUSTAKA}

\section{Komunikasi Politik}

A. Muis (1990), menjelaskan bahwa istilah komunikasi politik menunjuk pada pesan sebagai objek formalnya sehingga titik berat konsepnya terletak pada komunikasi dan bukan pada politik. Pada hakikatnya komunikasi politik mengandung informasi atau pesan tentang politik.Sedang McNair (1995) menyebutkan bahwa komunikasi politik adalah komunikasi yang diupayakan untuk mencari tujuan-tujuan politik tertentu. Kemudian Graber (1984) memandang bahwa komunikasi politik adalah 
proses pembelajaran, penerimaan, dan persetujuan atas kebiasaan-kebiasaan atau aturan-aturan, struktur, dan faktor-faktor lingkungan yang berpengaruh terhadap kehidupan politik. Selain itu, Astrid (1985) mengartikan komunikasi politik sebagai suatu komunikasi yang diarahkan pada pencapaian pengaruh sedemikian rupa sehingga masalah yang dibahas oleh jenis kegiatan komunikasi itu, dapat mengikat semua warganya melalui suatu sanksi yang ditentukan bersama oleh lembaga-lembaga politik.Dengan demikian, melalui kegiatan komunikasi politik terjadi pengaitan masyarakat sosial dengan lingkup negara sehingga komunikasi politik merupakan sarana untuk pendidikan politik/kesadaran warga dalam hubungan kenegaraan.Anwar Arifin menyimpulkan bahwa komunikasi politik adalah pembicaraan untuk memengaruhi dalam kehidupan bernegara (Arifin, 2011:8). Dari perspektif yang berbeda, Nimmo (1999:10) merumuskan komunikasi politik sebagai kegiatan yang bersifat politis atas dasar konsekuensi aktual dan potensial, yang menata perilaku dalam kondisi konflik.

Terdapat beberapa teori dan model dasar yang dapat digunakan dalam aplikasi komunikasi politik.Teori dan model dasar tersebut adalah (1) Teori Jarum Hipodermik atau Teori Peluru; (2) Teori Khalayak Kepala Batu (The Obstinate Audience); (3) Teori Empati dan Teori Homofili; (4) Teori Informasi dan Teori Nonverbal (Arifin, 2011: 102).Lebih lanjut masing-masing teori akan diuraikan sebagai berikut:

1. Teori Jarum Suntik (Hypodermic Needle Theory)

Teori jarum suntik berpendapat bahwa khalayak sama sekali tidak memiliki kekuatan untuk menolak informasi setelah ditembakkan melalui media komunikasi. Khalayak terlena seperti kemasukan obat bius melalui jarum suntik sehingga tidak bisa memiliki alternative untuk menentukan pilihan lain, kecuali apa yang disiarkan oleh media. Teori ini juga dikenal dengan sebutan teori peluru (bullet theory) (Cangara, 2009: 119-120).

Berdasarkan teori tersebut, komunikator politik (politisi, professional, dan aktivis) selalu memandang bahwa pesan politik apa pun yang disampaikan kepada khalayak, apalagi kalau melalui media massa, pasti menimbulkan efek yang positif berupa citra yang baik, penerimaan atau dukungan. Teori jarum dapat diaplikasikan atau digunakan untuk menciptakan efektivitas dalam komunikasi politik.Hal ini tergantung kepada sistem politik, sistem organisasi dan situasi, terutama yang dapat diterapkan dalam sistem politik yang otoriter, dengan bentuk kegiatan seperti indoktrinasi, perintah, instruksi, penugasan, dan pengarahan.Itulah sebabnya teori ini tetap relevan dan mampu menciptakan komunikasi yang efektif.Teori ini juga lebih memusatkan perhatian kepada efek afektif dan behavioral (Arifin, 2011: 102-105).

\section{Teori Khalayak Kepala Batu}

Teori ini dilandasi pemahaman psikologi bahwa dalam diri individu, ada kemampuan untuk menyeleksi apa saja yang berasal dari luar dan tidak direspons begitu saja. Teori kepala batu menolak teori jarum suntik atau teori peluru dengan alasan jika suatu informasi ditembakkan dari media, mengapa khalayak tidak berusaha berlindung untuk menghindari tembakan informasi itu.Masyarakat atau khalayak memiliki hak untuk memilih informasi yang mereka perlukan dan informasi yang mereka tidak perlukan.Kemampuan untuk menyeleksi informasi terdapat pada khalayak menurut perbedaan individu, persepsi, dan latar belakang sosial budaya.

Raymond Bauer mengeritik potret khalayak sebagai robot yang pasif.Khalayak hanya bersedia mengikuti pesan bila pesan itu memberi keuntungan atau memenuhi kepentingan dan kebuuthan khalayak.Komunikasi tidak lagi bersifat linear tetapi merupakan transaksi. Media massa memang berpengaruh, tetapi pengaruh itu disaring, diseleksi, dan diterima atau ditolak oleh filter konseptual atau faktor-faktor personal yang mempengaruhi reaksi mereka (Arifin, 2011: 105-106).

3. Teori Empati dan Teori Homofili

Secara sederhana dapat disebutkan bahwa empati adalah kemampuan menempatkan diri pada situasi dan kondisi orang lain. Dalam hal ini K. Berlo (1960) (dalam Arifin, 2011: 110) memperkenalkan teori yang dikenal dengan namainfluence theory of emphaty (teori penurunan dari 
penempatan diri kedalam diri orang lain). Artinya, komunikator mengandaikan diri, bagaimana kalau ia berada pada posisi komunikan. Dalam hal ini individu memiliki pribadi khayal sehingga individuindividu yang berinteraksi dapat menemukan dan mengidentifikasi persamaan-persamaan dan perbedaan masing-masing, yang kemudian menjadi dasar dalam mmelakukan penyesuaian.Dalam komunikasi politik, kemampuan memproyeksikan diri sendiri kedalam titik pandang dan empati orang lain memberi peluang kepada seorang politikus utnuk berhasil dalam pembicaraan politiknya. Akan tetapi, menempatkan diri sendiri sebagai orang lain itu memang sangat tidak mudah. Justru itu, empati dapat dtingkatkan atau dikembangkan oleh seorang politikus melalui komunikasi sosial dan komunikasi politik yang sering dilakukan.

Dengan demikian, empati dalam komunikasi politik adalah sifat yang sangat dekat dengan citra seseorang politikus tentang diri dan tentang orang lain. Itulah sebabnya empati dapat dinegosiasikan atau dimantapkan melalui komunikasi antarpersona.

Homofili dapat digambarkan sebagai suasana dan kondisi kepribadian dan kondisi fisik dua orang yang berinteraksi karena memiliki kebersamaan usia, bahasa, pengetahuan, kepentingan, organisasi, partai, agama, suku bangsa, dan pakaian. Dan Nimmo (1990) (dalam Arifin, 2011: 111) mengemukakan beberapa prinsip homofili dalam komunikasi, yaitu: pertama, orang-orang yang mirip dan sesuai satu sama lain lebih sering berkomunikasi daripada orang-orang yang tidak mempunyai persamaan sifat dan pandangan. Kedua, komunikasi yang lebih efektif terjadi bila sumber dan penerima adalah homofilistik karena orang-orang yang mirip cenderung menemukan makna yang sama dan diakui bersama dalam pesan-pesan yang dipertukarkan oleh mereka. Ketiga, homofili dan komunikasi saling memelihara karena makin banyak komunikasi di antara mereka, makin cenderung dapat berbagi pandang dan melanjutkan komunikasi.

\section{Teori Informasi dan Nonverbal}

Sejumlah pakar ilmu komunikasi telah mengembangkan teroi informasi yang banyak digunakan dalam kegiatan komunikasi politik. Teroi informasi (dan teroi sistem sosial) telah digunakan oleh B. Aubrey Fisher (dalam Arifin, 2011: 113) dalam menggagas dan menjelaskan paradigma pragmatis, yang intinya adalah bertindak sama dengan berkomunikasi, artinya semua tindakan politik dapat dipandang sebagai komunikasi politik yang bersifat non verbal. Sering juga dikatakan bahwa tidak ada komunikasi (verbal), tetapi ada komunikasi (nonverbal).

Dalam teori informasi menurut B. Abrey Fisher informasi diartikan sebagai pengelompokkan peristiwa-peristiwa dengan fungsi untuk menghilangkan ketidakpastian.Informasi dapat disebut sebagai konsep yang absolut dan relatif karena informasi diartikan bukan sebagai pesan, melainkan jumlah, benda dan energi. Jika dikaitkan dengan teori relativitas, bertindak pun merupakan sebuah informasi dalam arti sebuah kemungkinan alternatif yang dapat diprediksi berdasarkan pola (peristiwa dari waktu ke waktu).Informasi dalam komunikasi politik dapat berarti sikap politik, dan pendapat politik, media politik, kostum partai politik, dan temu kader partai politik.Menurut teori informasi, komunikasi politik adalah semua hal harus dianalisis sebagai tindakan politik (bukan pesan) yang mengandung sebuah kemungkinan alternatif. Jadi, bertindak (melakukan tindakan politik) sama dengan berkomunikasi (melakukan komunikasi politik).

Sesungguhnya komunikasi nonverbaladalah merupakan tindakan dalam peristiwa komunikasi politik yang dapat ditafsirkan secara berbeda-beda oleh khalayak.Justru itu tindakan itu harus diamati dari waktu ke waktu sehingga dapat ditemukan polanya.Jika pesan nonverbalitu berlangsung berulang-ulang, terbentuklah pola tindakan. Pola itu kemudian menjadi pedoman untuk melakukan prediksi pada masa depan. Artinya prediksi dilakuakan berdasarkan pola.Jika suatu saat terjadi tindakan di luar pola, maka terjadilah kejutan. 


\section{Komunikasi Politik dan Budaya Politik}

Terlaksananya segala fungsi dalam sistem politik termasuk komunikasi politik sangat dipengaruhi oleh budaya politik masyarakat di mana sistem politik itu berlangsung. Budaya politik (political culture) didefinisikan oleh Almond \& Powell sebagai suatu konsep yang terdiri atas suatu sikap keyakinan, nilai-nilai dan keterampilan yang sedang berlaku bagi seluruh warga masyarakat, termasuk pola kecenderungan-kecenderungan khusus serta pola-pola kebiasaan yang terdapat pada kelompok-kelompok dalam masyarakat. Sedang Miriam Budiardjo menulis bahwa budaya politik adalah keseluruhan dari pandangan-pandangan politik, seperti norma-norma, pola-pola orientasi terhadap politik dan pandangan hidup pada umumnya.Meskipun budaya politik merupakan sistem nilai dan keyakinan yang dapat dimiliki bersama individu-individu dalam masyarakat, namun Sidney Verba menunjukkan adanya beberapa perbedaan antara budaya politik yang berlaku di masyarakat dan yang hanya berlaku disuatu kelompok saja. Lucian Pye menyinpulkan bahwa antara elit dengan massa terdapat budaya politik yang berbeda, sehingga dalam suatu masyarakat terdapat budaya elit dan budaya politik massa (rakyat jelata) yang berbeda, terutama di Negara berkembang, seperti Indonesia (Arifin, 2011: 25-26).

Istilah budaya politik meliputi masalah legitimasi, pengaturan kekuasaan, proses pembuatan kebijaksanaan pemerintah, kegiatan partai politik, perilaku aparat negara, serta gejolak masyarakat terhadap kekuasaan yang memerintah. Kegiatan politik juga memasuki dunia keagamaan, kegiatan ekonomi dan sosial, kehidupan pribadi dan sosial secara luas.Dengan demikian budaya politik langsung memengaruhi kehidupan politik dan menentukan keputusan nasional yang menyangkut pola pengalokasian sumber masyarakat.Budaya politik merupakan sistem nilai dan keyakinan yang dimiliki bersama oleh masyarakat, tetapi setiap unsur masyarakat berbeda pula budaya politiknya, seperti antara masyarakat umum dan para elitenya. Menurut Benedict R.O.G. Anderson, kebudayaan Indonesia cenderung membagi secara tajam antara kelompok elite dan kelompok massa (Anggara, 2013: 112).

Dari realitas budaya politik yang berkembang di masyarakat, Gabriel Almond mengklasifikasikan budaya politik sebagai berikut (Anggara, 2013: 115-116):

1. Budaya politik parokial, yaitu tingkat partisipasi politiknya sangat rendah, yang disebabkan faktor kognitif (misalnya tingkat pendidikan relative rendah). Budaya parokial menyangkut budaya yang terbatas pada wilayah atau lingkup yang kecil, sempit. Karena terbatasnya diferensiasi, tidak ada peran politik yang bersifat khas dan berdiri sendiri. Yang menonjol dalam budaya politik adalah kesadaran anggota masyarakat akan adanya pusat kewenangan/kekuasaan politik dalam masyarakat.

2. Budaya politik kaula, yaitu masyarakat bersangkutan sudah relatif maju, tetapi masih pasif. Posisi sebagai kaula merupakan posisi yang pasif dan lemah. Mereka menganggap dirinya tidak berdaya memengaruhi atau mengubah sistem. Oleh karena itu, mereka menyerah pada segala kebijakan dan keputusan para pemegang jabatan. Sikap masyarakat pada umumnya menerima sistem itu, bersifat patuh (obedient), dan loyal.

3. Budaya politik partisipan, yaitu budaya politik yang ditandai dengan kesadaran politik sangat tinggi. Anggota masyarakat mempunyai kesadaran secara utuh bahwa mereka adalah aktor politik. Masyarakat memiliki sikap yang kritis terhadap sistem politik dan hampir pada semua aspek kekuasaan.

4. Budaya politik campuran (mixed political cultures), yaitu gabungan karakteristik tipe-tipe kebudayaan politik murni yang diuraikan di atas.

Almond dan Verba mengemukakan bahwa budaya politik suatu masyarakat dihayati melalui kesadaran masyarakat terhadap pengetahuan, perasaan, dan evaluasi masyarakat tersebut yang berorientasi pada (Anggara, 2013: 117-118): 
1. Orientasi kognitif, merupakan pengetahuan masyarakat tentang sistem politik, peran, dan segala kewajibannya. Termasuk di dalamnya adalah pengetahuan mengenai kebijakan yang dibuat oleh pemerintah.

2. Orientasi afektif, merupakan perasaan masyarakat terhadap sistem politik dan perannya, serta para pelaksana dan penampilannya. Perasaan masyarakat tersebut bisa saja merupakan perasaan untuk menolak atau menerima sistem politik atau kebijakan yang dibuat.

3. Orientasi evaluatif, merupakan keputusan dan pendapat masyarakat tentang objek politik yang secara tipikal melibatkan nilai moral yang ada dalam masyarakat dengan kriteria informasi dan perasaan yang mereka miliki.

\section{METODE PENELITIAN}

Pendekatan penelitian adalah kualitatif dengan desain deskriptif. Menurut Bagdan dan Taylor (dalam Moleong 2011:4) metode kualitatif adalah prosedur penelitian yang menghasilkan data deskriptif berupa kata-kata tertulis atau lisan dari orang-orang dan perilaku-perilaku yang dapat diamati. Denzin dan Lincoln (dalam Moleong 2011:5) mengatakan bahwa penelitian kualitatif adalah penelitian yang menggunakan latar alamiah, dengan maksud menafsirkan fenomena yang terjadi dan dilakukan dengan berbagai metode yang ada.

Fokus penelitian ini adalah kajian komunikasi politik legislator perempuan di DPRD Provinsi NTB. Untuk mendapatkan data dan informasi perlu ditentukan siapa yang menjadi subyek penelitian. Pada penelitian ini menggunakan teknik purposive sampling, yaitu teknik penentuan sampel dengan pertimbangan tertentu, Sugiyono (2009: 220). Jadi informan dalam penelitian ini adalah pihak-pihak yang diangap berkompeten dan mengetahui lebih banyak tentang komunikasi politik legislator perempuan di DPRD Provinsi NTB. Informan dalam penelitian ini adalah 2 anggota legislatif perempuan yang menduduki posisi strategis, yaitu ketua DPRD Provinsi NTB dan Ketua Komisi V Bidang Kesejahteraan Rakyat dan Pemberdayaan Perempuan.

Jenis data dalam penelitian ini adalah data primer yaitu data pokok yang dikumpulkan melalui wawancara yang bersumber dari informan, dan data sekunder yaitu data tambahan yang dikumpulkan melalui berbagai literatur yang terkait penelitian ini. Teknik analisis data yang digunakan dalam penelitian ini adalah analisis deskriptif, dengan menguraikan seluruh data dan fakta yang berhasil dikumpulkan dalam bentuk argumentasi.

\section{HASIL DAN PEMBAHASAN}

Budaya politik masyarakat dimana sebuah sistem politik berlangsung akan mempengaruhi pelaksanaan fungsi sistem politik termasuk didalamnya komunikasi politik. Budaya politik dalam masyarakat dipengaruhi oleh agama, tradisi, kesukuan, pendidikan, status sosial dan ekonomi, konsep dan sikap terhadap kekuasaan, kepemimpinan, intensitas komunikasi, media massa, kehadiran teknologi dan sejarah perkembangan dari sistem politik. Meskipun dikatakan bahwa budaya politik merupakan sistem nilai dan keyakinan yang dapat dimiliki bersama individu-individu dalam masyarakat, namun Sidney Verba (dalam Arifin, 2011: 26) menunjukkan adanya beberapa perbedaan antara budaya politik yang berlaku di masyarakat dan yang hanya berlaku disuatu kelompok saja. Bahkan Luciana Pye menyimpulkan bahwa antara elit dengan massa terdapat budaya politik yang berbeda, sehingga dalam suatu masyarakat terdapat budaya politik elit dan budaya politik massa (rakyat jelata) yang berbeda, terutama di negara berkembang seperti Indonesia.

Merujuk pada pendapat Sidney Verba di atas, serta berdasarkan hasil wawancara dengan informan penelitian, dapat disimpulkan bahwa komunikasi politik yang berlangsung dan berkembang di badan legislatif Provinsi NTB menunjukkan adanya perbedaan dengan komunikasi politik yang berkembang di masyarakat. Senada dengan pendapat Sidney Verba, Benedict R.O.G. Anderson (Anggara, 2013: 112) menyatakan bahwa kebudayaan Indonesia cenderung membagi secara tajam antara kelompok elite dan kelompok massa. Pada budaya politik Indonesia yang bersifat parokial kaula pada satu pihak dan budaya politik partisan pada pihak lain, masyarakat masih ketinggalan dalam menggunakan hak dan dalam memikul tanggung jawab politiknya akibat isolasi dari 
kebudayaan luar, pengaruh penjajahan, feodalisme, bapakisme, ikatan primordial. Pada pihak lain, kaum elite dan sekelompok massa lain merupakan partisipan yang aktif (Anggara, 2013:119). Pada level kaum elite budaya politik yang terbangun adalah budaya politik partisipan, dimana narasumber sebagai bagian dari golongan elite memiliki kesadaran yang utuh bahwa mereka adalah aktor politik, memiliki sikap yang kritis untuk memberikan penilaian terhadap sistem politik.

Partisipasi politik dan keterlibatan dalam mempengaruhi kebijakan politik dalam negara demokrasi adalah aktivitas yang sangat penting. Menurut Miriam Budiardjo partisipasi politik adalah kegiatan seseorang atau sekelompok orang untuk ikut serta secara aktif dalam kehidupan politik seperti memilih pimpinan negara, dan secara langsung atau tidak langsung memengaruhi kebijakan pemerintah (public policy). Sebagaimana tujuan komunikasi politik yaitu untuk memengaruhi kebijakan politik atau kebijakan publik.

Selain budaya politik yang mempengaruhi efektifitas komunikasi politik legislator perempuan, penerapan Teori Empati dan Teori Homofili juga menjadi kunci efektivitas komunikasi politik kedua informan sebagai legislator perempuan di DPRD Provinsi NTB. Dalam teori komunikasi politik, secara sederhana empati dapat dipahami sebagai kemampuan menempatkan diri pada situasi dan kondisi orang lain. Artinya, komunikan mengandaikan diri, bagaimana kalau ia berada pada posisi komunikator. Sehingga individu-individu yang berinteraksi dapat menemukan dan mengidentifikasikan persamaan-persamaan dan perbedaan masing-masing, yang menjadi dasar dalam melakukan penyesuaian. Dalam komunikasi politik, kemampuan memproyeksikan diri sendiri ke dalam titik pandang dan empati orang lain memberi peluang kepada seorang politisi untuk berhasil dalam pembicaraan politiknya. Sementara, homofili adalah suasana dan kondisi kepribadian dan kondisi fisik dua orang yang berinteraksi karena memiliki kebersamaan usia, bahasa, pengetahuan, kepentingan, organisasi, partai, agama, suku bangsa, dan pakaian.

Dalam wawancaranya, kedua informan secara eksplisit menyampaikan bahwa dalam melakukan komunikasi politik yang efektif untuk mempengaruhi kebijakan politik dibutuhkan empati, yaitu memahami situasi dan kondisi lawan komunikasi. Serta adanya kesamaan antar personal yang melakukan komunikasi politik, dalam hal ini kesamaan kepentingan dan gender. Komunikasi politik yang menggunakan paradigma ini dapat disebut sebagai komunikasi politik yang manusiawi, karena secara teknis komunikasi berlangsung dialogis. Empati dan homofili akan menciptakan suasana yang akrab dan intim, sehingga komunikasi politik dapat berjalan secara interaksional. Dalam hal ini interaksi yang berlangsung adalah interaksi antara dua subyek yang selevel, bukan antara subyek dengan obyek. Proses dialogis ini berlangsung secara horizontal, artinya dalam berinteraksi mempunyai derajat yang sama sehingga tidak ada politisi yang memberi dan menerima perintah.

Selain Teori Empati dan Teori Homofili, dalam kegiatan komunikasi politik legislator perempuan di DPRD Provinsi NTB juga diaplikasikan teori informasi dan nonverbal. Teori ini berpandangan bahwa bertindak sama dengan berkomunikasi. Artinya, semua tindakan politik dapat dipandang sebagai komunikasi politik yang bersifat nonverbal. Atau, tidak ada komunikasi (verbal) tetapi ada komunikasi (nonverbal). Fokus dalam teori ini adalah perilaku politik atau tindakan politik dalam bentuk ucapan (verbal) dan bukan ucapan (nonverbal) oleh seorang politisi dalam sebuah peristiwa komunikasi politik.

Berdasarkan wawancara dengan informan, peneliti berpandangan bahwa melalui tindakan non verbal informan memberikan informasi atau melakukan komunikasi kepada publik tentang siapa dan bagaimana dirinya. Tindakan politik dalam peristiwa komunikasi politik bertujuan untuk membentuk citra politik, yaitu gambaran seseorang tentang politik yang memiliki makna, meskipun terkadang citra ini dapat berbeda dengan realitas yang sesungguhnya atau tidak merefleksikan kenyataan objektif. Para politisi sangat berkepentingan dalam pembentukan citra politik dirinya melalui komunikasi politik. 
Meskipun terkadang citra tidak merefleksikan kenyataan objektif namun hal ini rupanya tidak berlaku bagi kedua legislator perempuan yang menjadi informan dalam penelitian ini. Melalui komunikasi politik, keduanya membuktikan kepada publik bahwa mereka adalah politisi perempuan yang mempunyai kompetensi di bidangnya. Kredibilitas sebagai komunikator menjadi faktor penting dalam melakukan komunikasi politik yang bertujuan untuk membangun citra diri. Sebagaimana yang dikatakan oleh Aristoteles, menekankan pentingnya faktor personal pembicara dalam retorika, yaitu masalah karakter yang dikenal dengan istilah etos. Dalam literatur komunikasi, etos diartikan sebagai kredibilitas komunikator. Kredibilitas adalah seperangkat persepsi khalayak tentang sifat-sifat komunikator, sehingga sesungguhnya kredibilitas tidak melekat dalam diri komunikator, tetapi melekat pada diri komunikan. Namun demikian, kredibilitas berkenaan dengan sifat-sifat komunikator yang selanjutnya disebut sebagai komponen kredibilitas. Hovland dan Wiss menjelaskan bahwa kredibilitas atau etos itu terdiri dari dua komponen, yaitu keahlian (expertise) dan dapat dipercaya (trust worthiness) oleh khalayak (Rakhmat, 2005: 256).

Komunikasi politik yang dilakukan oleh kedua informan berjalan efektif karena keduanya memiliki kredibilitas sebagai komunikator sebagaimana yang telah diuraikan di atas. Penilaian ini berdasarkan pengalaman peneliti pada saat proses wawancara berlangsung kedua informan menunjukkan personality yang positif yaitu kepribadian yang hangat dan bersahabat, serta keduanya mempunyai prinsip yang jelas dan tegas dalam menjalankan perannya sebagai legislator perempuan. Informan juga berkompeten sebagai legislator, pasalnya keduanya dalam menjawab pertanyaan tidak hanya jawaban normatif yang diberikan namun juga bersifat teknis di lapangan. Hal ini dipengaruhi oleh latarbelakang pengalaman kedua narasumber di dunia politik praktis yang tidak diragukan lagi.

Sebagaimana kita ketahui bahwa tugas badan legislatif antara lain membuat undang-undang dan penganggaran. Dalam merumuskan undang-undang serta membuat anggaran tentu melewati proses yang cukup alot antar individu ataupun kelompok, dan tidak menutup kemungkinan terjadi konflik atau perbedaan pendapat didalamnya. Oleh karenanya perlu ada konsensus antar individu atau kelompok yang berbeda pendapat tersebut.

Sebagaimana pendapat Arifin (2011: 263) bahwa konsensus dan kesepakatan dicapai setelah ada konflik atau perbedaan pendapat terhadap suatu masalah. Hal itu terjadi dalam rapat, persidangan, atau musyawarah untuk (1) menyusun undang-undang atau peraturan-peraturan; (2) menentukan program, kebijakan, dan pelaksanaan; dan (3) penetapan atau pemilihan personalia terutama pemilihan pucuk pemimpin (ketua, presiden, dan wakil presiden).

Dalam membangun konsensus seorang politisi harus mempunyai kemampuan berkompromi. Salah satu teknis dalam membangun konsensus adalah melalui lobi. Agar konsensus dapat tercapai melalui kegiatan lobi, maka seorang politisi harus menguasai masalah, serta mempunyai konsep diri yang positif, yaitu selalu berfikir positif, percaya diri dan yakin akan kemampuannya, merasa setara dengan orang lain, mampu memperbaiki dirinya, dan bersedia membuka diri. Modal dasar secara personal ini diperlukan agar dapat melakukan komunikasi politik secara efektif.

Ada beberapa faktor yang mendorong lahirnya kesediaan membuka diri, yakni adanya kesamaan karakteristik personal, daya tarik fisik, familiarity, kedekatan (proximity), dan kemampuan (competence). Hasil study menunjukkan bahwa orang-orang yang memiliki persamaan karakteristik personal, seperti kesamaan nilai-nilai, sikap, keyakinan, tingkat sosio ekonomi, agama, ideologi, atau partai politik cenderung saling menyukai. (Arifin, 2011: 266). Kesediaan membuka diri sebagai salah satu ciri kosep diri yang positif berkaitan dengan konsep homofili yang sudah diuraikan di awal. Adanya kesamaan nilai, sikap, agama, kepentingan, ideologi, suku, dan lain sebagainya, menjadi salah satu faktor bagi seseorang untuk dapat menjadi pribadi yang inklusif.

\section{SIMPULAN}


Berdasarkan hasil wawancara dengan dua informan penelitian dapat disimpulkan bahwa komunikasi politik legislator perempuan di DPRD Provinsi NTB dapat berjalan secara efektif karena dipengaruhi oleh faktor internal dan eksternal. Faktor internal yang dimaksud adalah kemampuan secara personal kedua politisi perempuan ini dalam melakukan kegiatan komunikasi politik, kedua informan penelitian ini mampu membangun konsep diri yang positif, mempunyai prinsip yang tegas dan tujuan yang jelas, menjadi pribadi yang terbuka, mempunyai kredibilitas dibidang yang digelutinya. Sementara faktor eksternal adalah budaya politik partisipatif di lembaga legislatif tersebut dan partai politik tempat politisi ini bernaung. Budaya politik yang demikian memberikan kesempatan yang sama untuk berpartisipasi aktif bagi seluruh anggota legislatif, tanpa mempersoalkan perbedaan gender, agama, nilai, keyakinan, ideologi, status sosial dan ekonomi, latar belakang pendidikan. Kegiatan komunikasi politik yang dilakukan oleh kedua informan bertujuan untuk mempengaruhi kebijakan politik atau kebijakan publik, terutama kebijakan yang terkait dengan pemberdayaan perempuan di NTB. Selain itu ditujukan untuk pembentukan citra diri politisi serta lembaga, baik partai politik ataupun badan legislatif itu sendiri.

\section{DAFTAR PUSTAKA}

Anwar Arifin. 2011. Komunikasi Politik: Filsafat-Paradigma-Teori-Tujuan-Strategi dan

Komunikasi Politik Indonesia. Yogyakarta: Graha Ilmu.

Anggara, Syahya. 2013. Sistem Politik Indonesia. Bandung: CV Puataka Setia.

Cangara, Hafied.2009. KomunikasiPolitik: Konsep, teori, danStrategi. Jakarta:

RajaGrafindoPersada.

Dan Nimo. 2004. Komunikasi Politik; Komunikator, Pesan, dan Media.Bandung: Remaja

Rosdakarya.

Moleong, Lexy, J. 2011. Metode Penelitian Kualitatif. Bandung: PT Remaja Rosdakarya.

Rakhmat, Jalaludin. 2005. Psikologi Komunikasi. Bandung: Remaja Rosdakarya.

Surbakti, Ramlan. 1999. Memahami Ilmu Politik. Jakarta: Gramedia

Sugiyono. 2009. Metode Penelitian Kuantitatif, Kualitatif dan R\&D. Alfabeta. Bandung 